\title{
Research on the effects of integrated resorts in Korea on gambling addiction
}

\author{
Chan-Ho Jin* \\ Department of Leisure and Gaming, Hanseo University, Seosan, Korea
}

This research discusses the effects of the integrated resorts centered around casinos being implemented in Korea. It particularly focuses on the symptoms and most recent definitions of gambling addiction such as physiological or psychological dependence from excessive gambling. This paper suggests that there is a high prevalence rate of pathological gambling in Korea. It provides an argument for prevention, early detection, and lastly, active and voluntary treatment. Furthermore, the study addresses the physiological pathway of gambling addiction and the physiological factors of gambling addicts to suggest exercise rehabilitation that are currently limited to psychological treatments.

Keywords: Pathological gambling, Rehabilitation, Gambling, Addiction

\section{INTRODUCTION}

In Korea, the legal gambling industry began with the implementation of horse racing in 1922. Now there are seven types including casinos, cycle racing, motorboat racing, Sports Toto, lottery, and bullfights. The Korean gambling industry started with horse racing having the initial market share and lottery tickets that were accessed relatively easily. However, with the enactment of the Special Act on the Assistance to the Development of Abandoned Mine Areas in 1995, a small casino in Gangwon Land opened to the public in 2000, including Korean citizens. In 2003, the main casino opened its doors and continued the growth of casinos. In 2009, casinos generated the highest revenue in the gambling industry 2.0734 trillion won in net sales for each casino. As of 2014, casinos have made 2.7992 trillion won net sales from one domestic casino and 16 foreigner-exclusive casinos (National Gambling Control Commission, 2015).

The Asian market is taking the lead in the international casino industry with investment from Las Vegas casino businesses in Macau and the legalization of casinos in Singapore. Macau's casino revenues surpassed Las Vegas in 2006 and were seven times Las Vegas revenues in 2013. These phenomena show the trend of the international casino market (Bae and Sim, 2014; Song et al., 2014). Such trend changes have made implementation of integrated resorts even more noticeable. Integrated resorts are a type of casino that began in Las Vegas and fully developed in Singapore. An integrated resort refers to a "multi-purpose resort with the casino as the foundation along with various facilities such as hotel, convention, exhibition facilities, concert hall, shopping centers, theme parks, museums, leisure sports facilities, etc." (Park and Park, 2014). As casinos increasingly become integrated resorts, casinos can expand their limited base of slot machines and table games; it is an ideal model leading to a healthier casino culture. It can also offset the business risks that resorts experience with casinos, so it is also an ideal model in terms of business as well. Currently, Korea also has a number of casinos (17) but 16 of these only target the limited foreign population. Thus, their facilities are limited in that they are not very large in size and operations focus around the casinos. From this, one of the largest casino companies in Korea, Paradise Group, has partnered with SEGA Sammy Holdings, a Japanese game company, to create a corporation called Paradise SEGA Sammy Co. Ltd. They are currently proceeding with the construction of an integrated resort named "Paradise City" in Yeong Jong Do, Incheon. Furthermore, Lippo
${ }^{*}$ Corresponding author: Chan-Ho Jin

Department of Leisure and Gaming, Hanseo University, 46 Hanseo 1-ro, Haemimyeon, Seosan 31962, Korea

Tel: +82-41-660-1494, Fax: +82-505-979-7959, E-mail: sportsman@hanseo.ac.kr Received: June 24, 2015/ Accepted: August 8, 2015
This is an Open Access article distributed under the terms of the Creative Commons Attribution Non-Commercial License (http://creativecommons.org/licenses/by-nc/3.0/) which permits unrestricted non-commercial use, distribution, and reproduction in any medium, provided the original work is properly cited. 
\& Caesars Consortium, a venture between Chinese and American companies, will be starting construction in late 2015. In addition, the government will also be selecting two more business operators in 2015 for new integrated resorts. Both show that the casino industry's growth will continue.

The growth of the casino industry from the Korean integrated resort business provides various leisure and tourism facilities. The attraction of foreign tourists can produce direct effects such as foreign currency and tax revenue, and indirect effects such as creation of jobs, additional profits, and vitalization of the local economy (National Gambling Control Commission, 2014). However, over the mid- to long-term, if locals are allowed, the negative effects such as decrease in productive industries and increase in social costs, etc. should also be considered. Such negative effects may not be explained in regular situations and may only be limited to pathological gamblers who have reached the state of gambling addiction. However, the social costs from gambling in Korea are estimated to be over 11 trillion won; in the U.S., there has been research reporting that the total social cost of the regions that have legalized the gambling industry exceeds the profit from the vitalization of the gambling industry. Such issues cannot be simply neglected because of their seriousness in terms of the psychological and social costs paid by the pathological gamblers, their families, and society. Therefore, there is a need for appropriate prevention, early detection of pathological gamblers, and active and voluntary treatments (National Gambling Control Commission, 2014).

\section{GAMBLING ADDICTION}

Addiction can refer to acute poisoning shown in bodily symptoms from harmful substances or psychological addiction of excessive immersion into a behavior or habit that is repeatedly committed to gain pleasure and satisfaction (Young and Rodgers, 1998; Smith, 2012). Such psychological addiction shows physiological or psychological dependence and is accompanied by tolerance and withdrawal. Gambling addiction is a chronic mental addiction of psychological dependence. Kim (2006) defines it as "a phenomenon where a person tries to control certain behaviors showing dysfunction at the individual or societal level but loses control and repeatedly commits those behaviors." Gambling addiction is a widely used term; however, it is not a technical term. In 1980, the American Psychiatric Association used the term pathological gambling as one of the impulse control disorders in the Diagnostic and Statistical Manual (DSM-III) for the first time; it was used again in DSM-IV with the same category and diagnosis. In DSM-5, published in 2013, the classification system has changed from impulse control disorders to addiction related disorders and the diagnosis has changed from impulse control disorder to disordered gambling (Petry and O'Brien, 2013). In addition, Gamblers Anonymous uses the term compulsive gambling and defines it as the status of involuntarily continuing to gamble out of the individual's control (Son and Jung, 2007).

\section{PHYSIOLOGICAL PATHWAY OF GAMBLING ADDICTION}

The addiction from behaviors and habits such as gambling addiction is known. The pattern of the brain's reward circuit is activated and dopamine flows through the ventral tegmental area (VTA) and nucleus accumbens (NAc; Nestler, 2005). Dopamine is one of the catecholamine-type neurotransmitters that converts to dopa from the tyrosine hydroxylase from the throsine and then is synthesized by dopa decarboxylase. It also plays a crucial role in personality, exercise control, awareness, emotional expression, neuroendocrine regulation, and control of the cardiovascular system. Disorders caused by dysfunction in dopamine include schizophrenia, Parkinson's disease, depression, and more. Gambling addicts who immerse into one behavior had a higher level of dopamine in their blood compared to non-addicts while gambling (Missale et al., 1998). It has also been reported that longer the duration of gambling participation, the higher the heart rate and bodily stress hormone blood level such as cortisol and norepinephrine (Meyer et al., 2000; Polter and Kauer, 2014). Gambling addiction is also known to increase depression levels; though there is still some controversy around the level of physical fitness, there have been reports on the dangers of cardiovascular diseases and the effects on obesity (Goodyear-Smith et al., 2006; Salomon et al., 2009).

\section{GAMBLING ADDICTION PREVENTION AND INTERVENTION}

In the research on gambling addiction, evaluation is very important because it provides objective data that becomes the criteria for pathological gambling prevention and treatment. The evaluation of gambling addiction often occurs using the prevalence rate of gambling addiction (the proportion of gambling addiction at a certain time in a population). It can be divided into an investigation that selects potential pathological gamblers from the 
general public and an investigation that selects from gamblers (Kim and Gho, 2009). Currently, the tools used universally to estimate the prevalence rate of gambling addiction include the South Oaks Gambling Screen (SOGS), DSM-IV criteria, National Opinion Research Center DSM Screen for Gambling Problems (NODS), and Canadian Problem Gaming Index (CPGI). In Korea, the National Gaming Control Commission created the Korean Gambling Behavior Scale (KGBS) that took Korean society's characteristics and culture into consideration.

From the data reported by the National Gaming Control Commission, the prevalence rate of pathological gambling in Korea is at $5.4 \%$ and decreased greatly from $7.4 \%$ in 2012. Compared to results in other leading countries, European countries (Sweden, United Kingdom) and New Zealand had the lowest rates of 1.4 $2.2 \%$, Australia and Canada were in the middle around 4.3$4.5 \%$, and Malaysia (an Asian country) had the highest with 14.6\% (National Gambling Control Commission, 2014). Despite the fact that accurate comparison is difficult due to the differences in estimation periods and tools, such results show that Korea's pathological gambling prevalence rate is at the higher end.

The optimal method to lower the prevalence rate of pathological gambling is to provide prevention for the general public and new gamblers. It would intervene appropriately before addiction occurs and provide therapeutic approaches, which are reported to be more effective than interventions after the addiction has occurred (Lee et al., 2015). However, related research on pathological gambling in Korea is still lacking and most research that exists assesses interventions in pathological gamblers who are already in the midst of disordered gambling. Moreover, there are few institutions that specialize in gambling addiction; therefore, the approachability is quite low and a system to create professionals is also nonexistent, prompting measures to handle these issues.

\section{CONCLUSIONS}

The integrated resort in Yeong-Jong Do, Incheon will become a new model in the domestic casino industry and will likely be helpful in the tourism industry and national economy as it was in Singapore and Macau. Furthermore, the prospects are that it will lead the growth of legalized gambling industry in the country. However, one cannot overlook the negative effect that the casinos of the integrated resort industry bring in addition to the positive effects, which increase the social costs. One of the most representative negative effects is gambling addiction where a person shows physiological or psychological dependence from excessive gam- bling. Gambling addiction is classified as an addiction-related disorder that is accompanied by tolerance and withdrawal and requires treatment. The domestic prevalence rate of gambling addiction is relatively high, but there is little research done on this and most treatment methods depend on psychological treatments only. As discussed previously, the pathway of gambling addiction occurs in a pattern of dopamine going through the VTA-NAc and is related to changes in stress and physiological indicators, such as cardiovascular diseases and obesity. Thus, intervention from a perspective of sports rehabilitation seems feasible. Furthermore, sports rehabilitation may be higher in approachability than psychological treatment, so it can serve as a useful tool in gambling addiction rehabilitation that requires prevention and early intervention. However, there is insufficient research on gambling addiction from the perspective of sports rehabilitation and it cannot completely replace psychological therapy. Therefore, it would be ideal to have a program that also simultaneously utilizes existing psychological therapy.

\section{CONFLICT OF INTEREST}

No potential conflict of interest relevant to this article was reported.

\section{REFERENCES}

Bae SH, Sim HB. Exploratory study on the MICE integrated resort using the cases of Marina Bay Sands. J Tourism Manag Res 2014;18:101-118.

Goodyear-Smith F, Arroll B, Kerse N, Sullivan S, Coupe N, Tse S, Shepherd R, Rossen F, Perese L. Primary care patients reporting concerns about their gambling frequently have other co-occurring lifestyle and mental health issues. BMC Fam Pract 2006;7:25.

Kim KH. Addiction and self-regulation: A cognitive neuroscience approach. Korean J Health Psychol 2006;11:63-105.

Kim KH, Gho SK. Studying gambling addiction in Korea. Korean J Health Psychol 2009;14:481-495.

Lee KM, Kang JH, Lee HK. A participation observation study on the processes and contents of casino gambling addiction. Korean J Soc Welf Stud 2015;46:31-58.

Meyer G, Hauffa BP, Schedlowski M, Pawlak C, Stadler MA, Exton MS. Casino gambling increases heart rate and salivary cortisol in regular gamblers. Biol Psychiatry 2000;48:948-953.

Missale C, Nash SR, Robinson SW, Jaber M, Caron MG. Dopamine receptors: from structure to function. Physiol Rev 1998;78:189-225.

Nestler EJ. Is there a common molecular pathway for addiction? Nat 
Neurosci 2005;8:1445-1449.

Park YS, Park YR. Analysis of creative economic effects on resorts complex. Glob Economic Rev 2014;26:117-148.

Petry NM, O'Brien CP. Internet gaming disorder and the DSM-5. Addiction 2013;108:1186-1187.

Polter AM, Kauer JA. Stress and VTA synapses: implications for addiction and depression. Eur J Neurosci 2014;39:1179-1188.

Salomon K, Clift A, Karlsdóttir M, Rottenberg J. Major depressive disorder is associated with attenuated cardiovascular reactivity and impaired recovery among those free of cardiovascular disease. Health
Psychol 2009;28:157-165.

Smith DE. The process addictions and the new ASAM definition of addiction. J Psychoactive Drugs 2012;44:1-4.

Son DS, Jung SY. A study of the issues and impact on pathological gamblers. Ment Health Soc Work 2007;26:377-407.

Song HJ, Byun JW, Lee CK. Korea casino's development plan for casino market change. Korean J Tourism Res 2014;29:1-22.

Young KS, Rogers RC. The relationship between depression and Internet addiction. CyberPsychol Behav 1998;1:25-28. 